\title{
Domination, Gender Difference and National Myths: The Discursive Structure of Bourgeois* Identity in the Basel Pageant of $1892^{* *}$
}

\author{
Philipp Sarasin (University of Basel)
}

The historical pageant (Festspiel) I analyse in this essay is a typical phenomenon: typical of the forms of bourgeois representations of popular sovereignty envisaged by Rousseau in his Letter to d'Alembert as open-air assemblies of the people on festive occasions; ${ }^{1}$ it is typical of the late nineteenth century with the inception of organized mass demonstrations and the politically motivated construction of a common past, i.e., of official memory; ${ }^{2}$ and finally it is typical of Switzerland, which between 1886 and 1905 experienced a genuine spate of historical pageants, that genre of open air theatrical event influenced by the concepts of Wagnerian music theatre which captivated thousands. ${ }^{3}$ In this essay I am not interested in providing a comparative analysis of typical cases. Instead, I would like to investigate, by means of a specific example, how an urban bourgeois ruling élite undertook an 'invention of tradition' (Hobsbawm) using particular symbols, metaphors and discourses in a play. It will become apparent that, in the course of constructing a tradition,

* Translator's note: The multi-layered German word 'bürgerlich' has been translated throughout this text as bourgeois, but its other meanings are sometimes present as well, as in the notion of the 'bürgerliches Festspiel', the pageant that is both bourgeois and civic.

** This essay is a much revised version of a chapter from my dissertation, Stadt der Bürger. Struktureller Wandel und bürgerliche Lebenswelt, Basel 1870-1900 (Basel and Frankfurt a.M., 1990). For their encouragement and criticisms I would like to thank Esther Baur Sarasin in particular, as well as Susanna Burghartz, Albert Schnyder, Manfred Hettling, Peter Schöttler, Valentin Groebner and Lyndal Roper. I am also grateful for the criticism offered by the editors of German History, which helped me to hone my arguments.

' Roger Chartier, 'Discipline et invention. Les fêtes en France XVe-XVIIIe siècle', Diogène 110 (1980), 51-71, p. 64; Mona Ozouf, 'La fête révolutionnaire et l'espace urbain', in Paul Hugger (ed.), Stadt und Fest. Zu Geschichte und Gegenwart der europäischen Festkultur (Stuttgart, 1987), pp. 89-102.

2 Eric Hobsbawm, 'Mass-Producing Traditions: Europe, 1870-1914', in Hobsbawm and Terence Ranger (eds), The Invention of Tradition (Cambridge, 1984), pp. 263-307, esp. pp. 267268.

${ }^{3}$ Martin Stern, 'Das Festspiel des 19. Jahrhunderts in der Schweiz', in: Volk-VolksstückVolkstheater im deutschen Sprachraum des 18.-20. Jahrhunderts (Proceedings of a Colloquium supported by the Centre National de la Recherche Scientifique held in Nancy from 12-13 November 1982), ed. Jean-Marie Valentin (Jahrbuch für Internationale Germanistik, Reihe A Kongressberichte, Vol. 15), (Berne, Frankfurt am Main and New York, 1986). 
hidden statements are being made about the present at the same time. One must proceed from a fundamental difference between the pageant in Switzerland and similar events in Germany: while in Germany the entire culture of festivals and pageants was marked by the ambivalent relationship between bourgeois claims to sovereignty and submission to the prevailing order, ${ }^{4}$ in Switzerland pageants always bore witness to the absence of a manifest ruler. Was it the 'sovereign people', in the Rousseauian sense, that celebrated itself here?

Historical pageants in Switzerland were spectacular events with lavish displays of actors, costumes and scenery. They required central logistics and generally received state (or cantonal) support. The occasion was always a real or constructed historical event that was to be commemorated, usually for the first time: a battle, a treaty of confederation (Bundesbrief), the granting of a city charter, etc. ${ }^{5}$ The 'Basel Unification Festival' held in July 1892 to commemorate the 500th anniversary of the legal and political 'unification' of the two cities of Gross-Basel (south of the Rhine) and Klein-Basel (north of the Rhine) in 1392 also celebrated such a newly constructed myth of origins. ${ }^{6}$ The three-day festivities on 9-11 July 1892 began on Saturday morning with the municipal authorities' official celebration. In the evening the guilds and guests of honour dined in a cordoned-off area, entertained by bands on the banks of the Rhine, while all around them (tens of ?) thousands took part in the popular festival proper. The high point, however, was the historical

${ }^{4}$ Dieter Düding et al. (eds), Oeffentliche Festkultur. Politische Feste in Deutschland von der Aufklärung bis zum Ersten Weltkrieg (Reinbek, 1988); Manfred Hettling and Paul Nolte (eds), Bürgerliche Feste. Symbolische Formen politischen Handelns im 19. Jahrhundert (Göttingen, 1993); Michael Maurer, 'Feste und Feiern als historischer Forschungsgegenstand', Historische Zeitschrift 253 (1991), 101-130.

${ }^{5}$ Georg Kreis, Der Mythos von 1291: Zur Entstehung des schweizerischen Nationalfeiertages (Basel, 1991); Beatrix Mesmer, 'Die Pflege des nationalen Sinnes', in: Helvetia unterwegs. Schweizerische Eidgenossenschaft-Ideen und Realitäten (14 lectures held at the University of Basel), (Basel, 1991), esp. pp. 44-45; Martin Stern, 'Das Festspiel des 19. Jahrhunderts in der Schweiz', pp. 190-193; cf. the list of the most important pageants in Martin Stern, 'Das historische Festspiel - Integration um den Preis scheinhafter Identităt', in François de Capitani and Georg German (eds), Auf dem Weg zu einer schweizerischen Identität 1848-1914. Probleme-Errungenschaften-Misserfolge (8. Kolloquium der Schweizerischen Akademie der Geisteswissenschaften 1985), (Freiburg, 1987), pp. 311-320; Rémy Chabron, 'Vom politischen Theater zum Festspiel', Schweizer Zeitschrift für Geschichte 27 (1977), 310ff; Edmund Stadler, 'Das nationale Festspiel der Schweiz in Idee und Verwirklichung von 1758 bis 1914', in Engler and Kreis (eds), Das Festspiel, p. 73.

${ }^{6}$ In the late fourteenth century the former Habsburg bailiwick [Vogtei] of Klein-Basel came under the jurisdiction of the Greater Council of the city of Basel (north of the Rhine). From the perspective of the late nineteenth century the two cities owed their unification to the military good fortune of the Swiss confederates [Eidgenossen] who with Duke Leopold of Habsburg killed the governor of Klein-Basel at Sempach in 1386, which represented the decisive starting point for a joint development of the two cities (cf. Rudolf Wackernagel, Geschichte der Stadt Basel, Vol. 1, (Basel, 1907)). Today the significance of the legal unification of Gross-Basel and KleinBasel in 1392 has been qualified to a great extent, particularly from the perspective of social and economic history. Cf. Werner Meyer, 'Der Zusammenschluss von Gross- und Kleinbasel im Spätmittelalter', in B. Meles and B. von Wartburg (eds), Leben in Kleinbasel: 1392, 1892, 1992 (Basel, 1992). 
pageant which was performed three times on a specially erected outdoor stage before a total of some 20000 enthusiastic spectators. One thousand and eighty amateur actors, $c .800$ singers from the Basel choral societies and 101 musicians participated in these performances under the hot afternoon sun. At any given time there were up to 1500 persons and 30 horses on the purpose-built stage, which measured $25 \mathrm{~m}$ deep, $40 \mathrm{~m}$ wide at the front and $28 \mathrm{~m}$ wide at the back. $^{7}$

\section{Approaching the Problem}

According to the sources, the audience's enthusiasm for the pageant was overwhelming. Only that old sceptic Jacob Burckhardt seems to have had anything derisive to say about the affair: 'Our existence here at present', he wrote to his friend Friedrich von Preen in Baden, 'is utterly dominated by one of the most senseless and gigantic festivals, which is set to begin eight days from now: the glorification of the year 1392, when Gross-Basel and Klein-Basel became one city...I, for my part, am naturally excused because of age, and am not obliged to participate, and if only the whole pathetic fraud passes without incident I shall be wholly satisfied. ${ }^{8}$

This enlightened sarcasm is reminiscent of our present-day perspective on such expressions of nationalism twisted into historical mythology. Does this mean that we should accept Burckhardt's view that the Basel Pageant was without any meaning, save perhaps that which he himself thought he recognized, that of a 'pathetic fraud'? Was the historical pageant simply a grandiose exercise in deception? Up until now most scholars have argued as follows: the textual basis of pageants usually lacks any historical meaning; ${ }^{9}$ performances should be interpreted solely in functional terms, which means emphasizing the growing need-generated by modern urban conditions-of all participants for identification, to which the pageant or processions, etc., responded by appealing to history. ${ }^{10}$ The pageant offers various social groups a common

${ }^{7}$ Basler Vereinigungsfeier 1892. Offizieller Festbericht (Basel, 1892) (referred to henceforth as Festbericht). Cf. Basler Gedenkfeier 9. 10. 11. Juli 1892. Offizielles Festalbum nach den Originalcostümbildern componirt u. gezeichnet von E. Breuermann (Basel, 1892). The terms 'Gedenk-' and 'Vereinigungsfeier' were both equally common and used interchangeably.

${ }^{8}$ Letter of 2 July 1892, in Jacob Burckhardt, Briefe. Vollständige und kritische Ausgabe. Mit Benutzung des handschriftlichen Nachlaßes (ed. Max Burckhardt), Vols. I-X. (Basel, 1949-1986), Vol. X, p. 36 .

' Georg Kreis, 'Das Festspiel-ein antimodernes Produkt der Moderne', in Balz Engler and Georg Kreis (eds), Das Festspiel: Formen, Funktionen, Perspektiven (Schweizer Theaterjahrbuch, No. 49, 1988, Schweizerische Gesellschaft für Theaterkultur), (Willisau, 1988), p. 192; Dieter Düding, introduction to his Oeffentliche Festkultur, p. 20; Hermann Bausinger, Volkskultur in der technischen Welt (Frankfurt am Main and New York, 1986), p. 130.

${ }^{10}$ Stern, 'Das historische Festspiel', p. 325; Peter Sprengel, 'Die inszenierte Nation. Festspiele der Kaiserzeit', Germanisch-romanische Monatsschrift 40 (NF), (1990), 273; Klaus Tenfelde, 'Adventus. Zur historischen Ikonologie des Festzugs', Historische Zeitschrift 235 (1982), 76 (on the entry of the victorious emperor see pp. 70-73). Excerpts from the pageants and preliminary drafts for pageants celebrating the victory over France in 1871 and the founding of the Reich are printed in Klaus Sauer and German Werth, Lorbeer und Palme. Patriotismus in deutschen Festspielen (Munich, 1971), pp. 52-78. 
experience and thus a possibility for identification-identification at once with the common history on display and with all those participating in the event. This, it is argued, serves the function of salvaging the disintegrating political and social consensus by appealing to an heroic common past. ${ }^{11}$ It has also been argued that, after the growth crisis of the 1880s and the Kulturkampf, particularly in Switzerland, a need for national reconciliation manifested itself in national festivals and pageants. ${ }^{12}$

This interpretive concept's capacity to explain the phenomena at hand is dubious. At those points where it claims that bourgeois pageants exercised an actual ideological influence over the working classes, at any rate, the integration thesis rests on shaky ground: at least in the case of the Basel pageant, the Social Democrats, so far as one can glean from their press, by no means let themselves be deceived by the 'pathetic fraud'. On the contrary, the organizing committee's patriotic 'unification' message was immediately ridiculed in the Social Democratic newspapers. ${ }^{13}$ The integration thesis also has the disadvantage of corresponding directly to the consciousness of the historical pageant's protagonists. For the organizers of the Basel unification commemoration of 1892 the festivities' significance lay in their capacity to exercise an integrative, even 'unifying' influence at a time of social tension and alienation in an increasingly anonymous large city. ${ }^{14}$ Must a historian intending to study the pageants share this perspective?

I do not deny that festive occasions of this kind have had integrative effects by offering possibilities for identification: every festival serves to unite the participants on some kind of common ground (if only for the ceremony itself). ${ }^{15}$ But I do not believe that it is very fruitful to stop at such notions of a 'need for identification', which not infrequently rest on a rather vague mass psychology. After all we usually do not know what the spectators thought of what they saw, but we do know precisely what the actors on the stage said. In this essay I will be pursuing what was said, and offering a viewpoint opposed to that of the integration thesis.

I proceed from the observation that the integration thesis contains contradictory elements: it implies either that every word uttered in a pageant was conscious, even strategically ideological speech or, in contrast, that the text was completely meaningless, and the theatrical presentation mere aesthetic expression with 'elements that unleashed many emotions and created a

${ }^{11}$ Stern, 'Das Festspiel des 19. Jahrhunderts in der Schweiz', p. 201. See also Dietz-Rüdiger Moser, 'Patriotische und historische Festspiele im deutschsprachigen Raum. Ein Versuch in zehn Thesen und einer Vorbemerkung', in Engler and Kreis, Das Festspiel, pp. 51f.

${ }_{12}$ Thomas Widmer, Die Schweiz in der Wachstumskrise der 1880er Jahre (Zurich, 1992), pp. 639-641, 650-656.

${ }_{13}$ Basler Arbeiterfreund, 9 July 1892.

${ }_{14}$ See the organizing committee's appeal, signed by the Regierungsrat and committee president Philippi and committee secretary Rudolf Wackernagel, Allgemeine Schweizer Zeitung, 6 July 1892.

${ }^{15}$ Chartier, 'Discipline et invention', p. 51. 
mood' ${ }^{16}$ In both versions the integration thesis denies the imaginary as a social phenomenon reducible neither to functional logic nor to mere nonsense and pure meaninglessness, nor to the simple expression of 'moods'. Instead, the imaginary must be regarded as part of the social construction of reality. ${ }^{17}$ In the face of a sometimes naive constructionism, however, one must emphasize that the subjects themselves are only dimly aware of the imaginary creations of such world- and meaning-producing construction processes. Rather, they develop their own logic as cultural products: they work with existing linguistic material which the authors of such texts can never fully control. I will argue that, alongside all the explicit and intended messages, meanings appear on the pageant text's non-intentional levels of signification that were not 'meant' by the authors and performers and of which they were unaware, but which nevertheless made the spectacle as fascinating as it was for all participants.

Contemporaries and historians alike are not necessarily altogether wrong when they claim that the intended meaning was the integration of nonbourgeois strata into a social consensus. The psychoanalytically inspired approach used here, however, allows the assumption that in essence (if only implicitly), the bourgeois pageant was precisely not addressed to the potentially non-integrated social groups, but rather that on these non-conscious levels the pageant was an interior conversation, a text about bourgeois conflicts in society and bourgeois proposals for their resolution. Proceeding from this hypothesis has far-reaching methodological implications: as a nonconscious interior conversation the text of the pageant, which we have sweepingly assigned to the social imaginary, bears a striking resemblance to the metaphorical language of dreams as analysed by Freud. In the following I shall attempt to show what this might mean.

The Basel pageant is imbedded in the social, economic and political situation of the city of Basel at the end of the nineteenth century, ${ }^{18}$ which I have deliberately chosen not to introduce as the precondition for understanding it. I do not intend to begin with the 'hard' socio-historical 'base' from which perspective the pageant, as a mere 'superstructural' phenomenon, would apparently hold no more mystery. Rather, I shall work the other way around and begin with the pageant. Using the method of the interpretation of dreams' I shall attempt to show that, seen through the veil of the historicizing masquerade, elements of this industrial city's 'reality' become visible which are usually censored in a democratically organized bourgeois society. In the pageant a 'truth' appears which could no longer be expressed in another form.

${ }^{16}$ Düding, introduction, p. 20.

17 Peter L. Berger and Thomas Luckmann, Die gesellschaftliche Konstruktion der Wirklichkeit. Eine Theorie der Wissenssoziologie (Frankfurt am Main, 1977) (Garden City, NY, 1966).

${ }_{18}$ Sarasin, Stadt der Bürger, esp. Part I (pp. 13-130); see also L. Burckhardt, R. L. Frey, et al. (eds), Das politische System Basel-Stadt. Geschichte, Strukturen, Institutionen, Politikbereiche (Basel and Frankfurt am Main, 1984). For an overview of Swiss history in this period see Roland Ruffieux, 'Die Schweiz des Freisinns (1848-1914)', in: Geschichte der Schweiz-und der Schweizer, Vol. III (Basel and Frankfurt am Main, 1983), pp. 9-100. 


\section{The Pageant's 'Histories'}

The author of the pageant text was Rudolf Wackernagel, historian, Secretary of the Basel executive council and state archivist. He composed four not particularly dramatic 'living tableaux' as hymns of praise to the city (the pageant was to be nothing less), which the composer Hans Huber set to music:

\section{Scene 1: The Founding of Basel by the Romans in $374 A D$}

The pageant begins with a band of Roman legionnaires, led by the Emperor Valentinian, who come to disrupt the tranquil, natural existence of the Rauraci on the banks of the Rhine. Valentinian decides to found the city of Basel on the hill above the river where the cathedral and palace would later be erected, and to conquer the people living along the river.

That, of course, was pure fiction. As Wackernagel commented in the 'Short Outline of the Pageant' printed in the programme brochure, 'the documented presence of Emperor Valentinian I in the year 374 on the spot where Basel exists today, on the occasion of which the already existing settlement was given the name Basilia, has, with permissable licence, been reinterpreted as the founding of the city'. ${ }^{19}$ In fact, as a professional historian Wackernagel was familiar even then with the most important elements of the city's origins as we know them today: in his own 1907 Geschichte der Stadt Basel he wrote that 'Basel did not emerge from the Roman fort, nor from the bishops' castle; it arose and developed alongside them'--and not only earlier than the Roman fortifications on the cathedral hill but also differently and elsewhere: in the 'fluvial plain' and not as a 'castle' on the cathedral hill. In addition 'it was formed at a traffic junction, and its character corresponded to such a site' ${ }^{20}$ Yet Wackernagel reinterpreted this history: the historian as poet stretched it so far that in his version a foreign emperor subjugated the people on the river and he, the foreigner, not the people, founded the city.

\section{Scene 2: The Construction of the Bridge over the Rhine in 1225}

In the second scene we see the populace of Basel standing by the Rhine lamenting: the raging river has dragged a ferryman and a merchant with his wares down into the deadly flood. The citizenry asks for help from the city's ruler, Bishop Heinrich of Thun, who thereupon orders the construction of a bridge between the two Basels. The townswomen sing their thanks to the city's ruler:

${ }^{19}$ Officieller Festführer der Basler Gedenkfeier, 9, 10 u. 11 Juli 1892 (ed. by Organisationscomité) (Basel, 1892), p. 13.

${ }^{20}$ Wackernagel, Geschichte der Stadt Basel, Vol. 1 (Basel, 1907), p. 15. That the Raurici were already settled at the Basel bend in the Rhine before Roman times was known from Caesar's Gallic Wars. 
(... thou,) whose paternal gift

has lifted forever many a care

Blessed art thou, who art

wise and merciful. (162) ${ }^{21}$ This second scene of the pageant also has a central point of reference: the ruler. Here it is the bishop, lord of the two cities of Gross-Basel and Klein-Basel, which are connected by the bridge, who appears as a benevolent father and generous donor. This father-ruler installed by Rome stands in the same relationship to the people as the Roman emperor, the city founder who at the end of the first scene was equally celebrated by the populace. The parallel is striking, for it, too, rests on a fiction: in his historical account Wackernagel describes the city's ruler, who was allied to the local aristocracy, as a prince in constant conflict with the town council whose independence he restricted. ${ }^{22} \mathrm{He}$ also knew that the construction of the bridge was by no means the work of the bishop-instead the council appears to have been the prime mover" ${ }^{23}$

\section{Scene 3: Rudolf of Habsburg in Klein-Basel (1285)}

The scene shows the entry of King Rudolf of Habsburg and his knightly entourage into Klein-Basel where he granted the city its 'freedom'. Dancing lads and maidens and the craft guilds pay homage to the ruler and the entire choir cheers the noble lord:

Hail to the king, splendid in victories,

powerful in the gifts of his kindness

praise, glorify and bless him! (168)

Up until this point, the pageant has unfolded the content of the structure 'populace/citizens vs. ruler/foreigner' from military conflict (Rauraci/ Romans) to the successful accomplishment of the act of subjugation: the freedom granted by the ruler, which legitimates the ruler and satisfies the populace, without changing the basic structure of their relationship. To be sure, amidst the continuing cheers of the people for the king in the third scene the original antagonism between populace and foreign ruler melts into the harmony of apparently conflict-free relations, a circumstance already prefigured in the second scene, but it does not disappear, remaining rather the central axis of the text. A further element also persists: the account's

2l In what follows I cite the pageant text, which was printed as an appendix to the official programme ('Festspiel', by Rudolf Wackernagel, in Festbericht, pp. 151-178). The numbers in parentheses refers to the pages in the pageant text.

22 Wackernagel, Geschichte der Stadt Basel, pp. $21 \mathrm{f}$.

23 Ibid. 22. 
fictionality. Wackernagel well knew that the granting of citizens' rights to bondsmen from elsewhere 'within a year' was an act of privileging that went without saying, that was indeed normal, and benefited the bishop as the ruler of the city. ${ }^{24}$ In the pageant, in contrast, the king appears as a gracious lord who grants the people's 'long-standing desire'. And yet the poet Wackernagel then wrote as an historian 'however little his [the King's] general policy favoured the towns, treating the towns under his own rule with particular severity, so little was it his intention here to benefit the people of Klein-Basel. Whatever they received was theirs because of the bishop' ${ }^{25}$ Wackernagel systematically attributed to foreign rulers, whom he described as cheered on by the populace, a dominant role which they never occupied in the historical situations depicted.

\section{Scene 4: The Battle at Sempach and the Unification of Gross-Basel and} Klein-Basel (1386)

Accompanied by the curses of the citizenry, the governor of Klein-Basel, Leopold of Austria, and his knights from the local nobility do battle against the confederation peasants. And, lo and behold, the unbelievable occurs: the messenger from Sempach brings news of the confederates' victory and the death of the lord of Klein-Basel. The citizens of both towns resolve upon the political unification of Gross-Basel and Klein-Basel.

Before the open stage there follows an epilogue-like ending with a report by Helvetia, Basilea, and Clio on the subsequent development of the story from the unification of the two Basels to the entry of Basel into the Swiss confederation in 1501. The play ends with actors and spectators joining together to sing the national anthem: If thou callest, fatherland... [Rufst du mein Vaterland...]. This concluding rendition of the national anthem, uniting actors and audience, is a condensation of all that has been portrayed, reducing it to its core of national values and symbols, putting [back] the expression of historical and mythical contents into the mouths of the spectators.

The reversal in the final scene is total. Not only does the citizenry triumph all at once over its ruler, but the text now suddenly follows historical 'reality' such as it was recognized at the time, intertwined with mythical interpretations. In those days Basel was not yet a member of the Swiss confederation (it did not enter until 1501), but rather a free imperial city, belonging to the territory of the Habsburgs: Duke Leopold III of Austria was the imperial governor (Reichsvogt) of (Gross-) Basel south of the Rhine and also in reality owner and lord of the smaller settlement of Klein-Basel to the north. According to

${ }^{24}$ See ibid., p. 203.

25 Ibid. 202. 
the interpretation of late nineteenth-century historians, ${ }^{26}$ the defeat of a Habsburg knightly army by the Swiss peasant troops near Sempach in 1386 freed the town from the growing demands of the Duke, who wanted to expand his power over Gross-Basel from administration to sovereignty. Even if we know today that 'the events surrounding the acquisition of Klein-Basel by Gross-Basel cannot be tied to the battle of Sempach', ${ }^{27}$ the notion that the defeat at Sempach paved the way for the legal 'unification' of the two towns in $1392^{28}$ corresponded to the state of knowledge at the time. It was the explicit intention of the unification celebration to commemorate this. Thus the text was, in actuality, practically dictated here, leaving little room for much fictional 'storytelling'.

The fact of the unification of the two parts of the city, which was finally celebrated in 1892, was, however, not the only area that left the author little room for historic license. The myth of 'Sempach' also fixed the message. After all, the memory of the battle at Sempach in 1386 and particularly the myth of the hero Winkelried, who sacrificed his life to make possible the confederates' victory, belonged to the core ideas of national identity and the ideology of a free Switzerland, subject to no overlord. Particularly in the first decades after the real test of the Sonderbund War in 1847, which divided the Catholic, rural, original cantons and the Protestant, partially industrialized cantons into enemy camps, Winkelried functioned 'as a figurehead for national integration' ${ }^{29}$ Liberty, national unity, and the struggle against foreign rulers were integral components of one and the same conviction. Thus when Leopold and his knights marched into battle, the citizen Thüring Schönkint could call after him:

Oh go to thy death, though strangler, to a terrible, agonizing death!

Your evil angel guides each enemy weapon towards your head, and in the torments of your mortal hour, look about you look around at your friends' bitter death hear their groans, their final cries look upon your dynasty's demise in this land and die despairing! (171f.)

${ }^{26}$ See ibid., pp. 309-312, and Andreas Heusler, 'Wie Gross- und Kleinbasel zusammenkamen', in Historisches Festbuch zur Basler Vereinigungsfeier 1892 (Basel, 1892), pp. 28-35.

${ }^{27}$ Meyer, 'Der Zusammenschluß von Gross- und Kleinbasel im Spätmittelalter', p. 20.

${ }^{28}$ See Wackernagel, Geschichte der Stadt Basel, pp. 312, 318, 325.

${ }^{29}$ Beat Suter, Arnold Winkelried, der Heros von Sempach. Die Ruhmesgeschichte eines Nationalhelden (Beiheft 17 to Der Geschichtsfreund), (Stans, 1977), p. 335. See also Die Schlacht von Sempach im Bilde der Nachwelt (exhibition catalogue 600 Jahre Stadt und Land Luzern), ed. Heinrich Thommen (Lucerne, 1986). 
This yearning desire for the death of the same lords that populace and citizenry had just spent three scenes lauding as victors, fatherly benefactors, and liberators now suddenly inverts the meaning of the structure people/ citizens $v s$. ruler/foreigner. When the unexpected news of the peasant victory arrives, then, the citizens cheer-'now we are free of our oppressor'-and decide upon the union of the two towns with the sudden new knowledge:

and thus united we defy the Bishop, confidently we defy the Duke's heirs; for we are strong, if only we stand together. (174)

This happy ending to the story presents us with some thorny questions: why did Wackernagel falsify history in the first three scenes, if this necessarily stood in incomprehensible contradiction to the final scene dictated by the Winkelried myth? Why were the foreign lords first celebrated-contrary to the facts-if the celebration of their death was intended to appear as the play's actual meaning? In short: What was really being said here?

The pageant, with all its contradictions and inconsistencies, resembles a dream, that psychic phenomenon that confronts the waking person with as many riddles as the reader of Wackernagel's text. This statement is doubtless rather audacious: its implications are, naturally, directly connected with Freud's conception of dreams as developed in his Interpretation of Dreams (first published in 1900), and it doubtless arouses immediate misgivings. One need not look far to find potential objections to my approach: how can a pageant resemble a dream when dreamers sleep but the author and audience of the pageant are wide awake and acting very consciously; when dreams are usually confused and bewildering, while the pageant's illustration of the town's history was clear, if inconsistent; when dreams are private psychic acts which, upon waking, are usually scarcely accessible even to the dreamer, while the pageant was a collective, public event whose meaning apparently made sense to everybody? And is Peter Burke not correct when he accuses Freud of viewing the dream completely ahistorically as a mere manifestation of individual desires and universal symbols and of denying any connection to social reality $?^{30}$ The pageant, whose contradictions we find disconcerting today, enchanted thousands at the time: as in a dream, something must have been said there that may not have been directly 'understood' but that was still experienced by all participants as in some way 'true'. Let us follow this trail by not examining the text's immediate referential function, i.e., by not setting

\footnotetext{
${ }^{30}$ Peter Burke, 'L'histoire sociale des réves', Annales ESC 2 (1973), 329-30: 'C'est pour sa négligence d'un troisième niveau de signification, le niveau social [alongside 'universal' and 'individual' meanings], que la théorie classique [Freud] peut être, à plus juste titre, critiquée' (p. 330).
} 
it in direct relation to a social 'reality' ${ }^{31}$ Rather, I should like to investigate the way in which the text produced 'meaning'. In so doing I proceed from the suggestions Freud and Lacan have made for the analysis of dreams and similar manifestations of the unconscious, particularly Lacan's reading of the Freudian categories of condensation and displacement as linguistic tropes, as metaphor and metonymy, i.e., as phenomena of real, historically changeable, and historically shaped language. ${ }^{32}$ Lacan's fundamental thesis that the unconscious is structured like a language means that there is a buried significance in the network of metaphors in any text (and not simply in the marginal special case of dream memories) which in the context of an individual consciousness we call unconscious, ${ }^{33}$ which in the context of non-individual texts (such as the pageant), however, we may refer to as a non-conscious subtext, as 'another meaning', 'another discourse', which intervenes in the manifest discourse. ${ }^{34}$ Such texts have meaning for or fascinate the spectators, for example, because this discursive structure, this intervention of 'another meaning' into the manifest discourse, corresponds to some degree to the linguistic structuring of their own unconscious. Otherwise they would have been bored or ridiculed the contradictions in the text.

Alongside this discourse analytic method of dream-interpretation, however, there is also a second one: Freud called an interpretation of dreams that did not proceed from the dreamer's associations but solely from the interpretation of symbols and general 'linguistic exercises' a 'secondary and auxiliary method of dream-interpretation'. ${ }^{35}$ In contrast to the genuinely analytic method, this auxiliary method relies more strongly, along with the interpretation of symbols, on an often detailed knowledge of the dreamer's concrete (historical) situation. On this everyday level of historical reality, one may use 'normal'

${ }^{31}$ Roger Chartier, 'Le monde comme représentation', Annales ESC 6 (1989), 1508-1511, 1514. See also Peter Schöttler, 'Mentalitäten, Ideologien, Diskurse. Zur sozialgeschichtlichen Thematisierung der "dritten Ebene", in Alf Lüdtke (ed.), Alltagsgeschichte. Zur Rekonstruktion historischer Erfahrungen und Lebensweisen, (Frankfurt am Main and New York, 1989), pp. 85136, esp. the introductory remarks on p. 85. English: 'Historians and Discourse Analysis', trans. Hilary Pilkington and Chris Turner, History Workshop Journal 27 (1989), 37-65.

${ }_{32}$ Sigmund Freud, The Interpretation of Dreams (Penguin Freud Library, Vol. 4) (London, 1991), pp. 383-419; Jacques Lacan, 'L'instance de la lettre dans l'inconscient ou la raison depuis Freud', in Lacan, Ecrits (Paris, 1966), pp. 493-528; English: 'The agency of the letter in the unconscious or reason since Freud', in: Ecrits. A selection (trans. Alan Sheridan) (London and New York, 1977), pp. 146-78. See also Johannes Fehr, 'Das Unbewusste und die Struktur der Sprache. Studien zu Freuds frühen Schriften' (Phil. Diss. Zurich, 1987); Emile Benveniste, Remarques sur la fonction du langage dans la découverte freudienne, in his Problèmes de linguistique générale, Vol. 1 (Paris, 1966), pp. 75-87; Michel Pêcheux et al., 'La sémantique et la coupure saussurienne: langue, langage, discours', in D. Maldidier (ed.), L'inquiétude du discours, Textes de Michel Pêcheux (Paris, 1990).

${ }^{33} \mathrm{Cf}$. Freud, The Psychopathology of Everyday Life (Penguin Freud Library, Vol. 6) (London, 1991).

${ }^{34}$ Michel Pêcheux, 'sur les contextes épistémologiques de l'analyse de discours', Mots 9 (1984), 7-17.

${ }^{35}$ Freud, The Interpretation of Dreams (Pelican Freud Library, Vol. 4) (London, 1976), p. 339 ; cf. pp. $457 \mathrm{f}$. 
historical methods to find clues that, together with the decoding of the "chain of signifiers' (Lacan) may contribute to the deciphering of dream-pictures. For dream-pictures conceal a text about the life of the dreamer ('real or imaginary events ${ }^{36}$ ), a dream-thought, in short: a meaning. To be sure, this cannot be reduced functionally to mere 'external', 'objective' reality, but it doubtless has something to do with the subjective perception of external realities. Alongside the historical materiality of language towards which the discourse analytic method is directed, this level of 'circumstantial evidence, ${ }^{37}$ is thus the second point of intersection between historical method and the psychoanalytic approach to interpretation. ${ }^{38}$

\section{Woman, River, Ruler}

The first scene of the pageant lays out the basic narrative patterns which will determine the entire play. The scene begins with the song of a young woman sitting by the river and dreaming of her beloved:

Softly the stream murmurs on, the morning wind rustles light, from the mountains all around the darkness soon takes flight.

She sings of the previous night,

when my beloved returned to me

through the raging torrent

he forced his frail boat o'er

to me, daring and brave

he called up to the place I stood

many a sweet loving word.

I greeted him and he turned about

and set sail for his own home port.

Over on the other shore

A small house in a thicket stands

T'is there that my beloved lives

The lord of his own lands. (151f)

A woman by the river, a raging torrent (Flut), a loving word, a thicket: the historical pageant on the history of the city of Basel begins with powerful

${ }^{36}$ Ibid. 394. See Freud's remarks on 'circumstantial evidence' in connection with the interpretation of parapraxes in Introductory Lectures on Psychoanalysis (Pelican Freud Library, Vol. 1) (London 1973), pp. 78 ff.

37 Introductory Lectures (Vol. 1), pp. $78 \mathrm{ff}$.

38 What 'microhistory' or 'thick description' seeks to uncover for the historian's gaze corresponds precisely to 'circumstantial evidence', Freud's 'smallest details'. 
images. What do they mean, what is the 'semantic relationship' (Zeichenbeziehung, Freud) between the woman, the torrent and the loving word? The question does not seem all that difficult to answer: German literature alone is filled with imagery of women on or in rivers-Ophelia, Undine, Melusina, sirens, and aquatic women more generally. ${ }^{39}$ Songs and poems about the Rhine tell in countless variations the story of the temptress on the river. ${ }^{40}$ Goethe's 'Fisherman', for example, sinks beneath the waves because a 'wet woman' seduced him. ${ }^{41}$ Equally deadly was an encounter with the Lorelei on her rock, a woman on the water who drew besotted boatmen to their doom beneath the waves. ${ }^{42}$ The woman on/in the water is also a frequently recurring theme in Eichendorff's poetry. The figure of the nixie metaphorically combines intoxicating sensuality with death on the 'silent bed' of a forest lake or river: the nixie is a metaphor for the impending dissolution of the (man's) ego into night and nature should he succumb to the temptress' seduction. ${ }^{43}$ As metaphors for wildness, nature, and eros, the forest, the wilderness, or, as it is called in the pageant, the jungle, also belong in this context.

We may safely assume that these associations were present in the minds of Basel's citizens when they decided that the 1892 pageant, which had been composed by Wackernagel, a cultivated bourgeois from a German academic family, should begin at the river with the 'Maiden's Song'. In its account of the celebrations, the Allgemeine Schweizer Zeitung, at any rate, interpreted the stanzas sung by the 'young woman', 'her happiness and her longing beside the rushing river' simply as 'lyric poetry of maidenly feeling' ${ }^{44}$ in other words woman, stream, eros. The original-in Wackernagel's conception prehistoric-life of the people on the fluvial plain ${ }^{45}$ is represented in the text by

${ }^{39}$ See, for example, the anthology Undinenzauber. Geschichten und Gedichte von Nixen, Nymphen und andere Wasserfrauen (ed. Frank Rainer Max) (Stuttgart, 1991). Among the literature on the topic see also Inge Stephan, 'Weiblichkeit, Wasser und Tod. Undinen, Melusinen und Wasserfrauen bei Eichendorff und Fouqué', in Renate Berger and Inge Stephan (eds), Weiblichkeit und Tod in der Literatur (Cologne and Vienna, 1987), pp. 117-39; Karin Hanika and Johanna Werckmeister, "wie ein Geschöpf, geboren und begabt für dieses Element". Ophelia und Undine-Zum Frauenbild im späten 19. Jahrhundert', in Berger and Stephan (eds.), Weiblichkeit, pp. 141-154; Matthias Vogel, 'Melusine... das läßt aber tief blicken.' Studien zur Gestalt der Wasserfrau in dichterischen und künstlerischen Zeugnissen des 19. Jahrhunderts, (Europäische Hochschulschriften, Series XXVIII, Vol. 101) (Berne, Frankfurt am Main, New York, and Paris, 1989).

${ }^{40}$ See, for example, Max von Schenkendorf, 'Am Rhein', in Wolf-Dietrich Gumz and Frank J. Hennecke (eds), Rheinreise-Gedichte und Lieder (Stultgart, 1986), pp. 105-106.

41 Johann Wolfgang von Goethe, 'Der Fischer', in Undinenzauber, pp. 272-273.

${ }^{42}$ See, for example, Justus Wolff in Rheinreise, p. 133.

${ }^{43}$ Stephan, 'Weiblichkeit, Wasser und Tod', pp. 117-122.

44 Allgemeine Schweizer Zeitung, 12 July 1892.

${ }^{45}$ In his 'brief sketch of the pageant' he speaks of the 'establishment of Roman rule and with it the beginning of historic life'. Officieller Festführer, p. 13. 
the 'maidenly feeling' of the woman at the river, that is, by her waiting for her beloved. The latter struggles to reach her across the 'raging torrent', but in the end only calls 'many a sweet loving word up' to her and returns to the other shore. While she waits, suspended, for the man who will not turn back again,

the enemy approaches with a roar

through the woods the sounds of war

ring out and armour shimmers (152)

In other words, the Romans invade, carrying their 'eagles'

to the summit of this hill

gleaming in the morning sun

far above the stream and vale

announcing all across the land

that we sojourn here as lords. (153)

On the hill above the fluvial plain, as we know, Emperor Valentinian founds the town, or more precisely, the castle.

A bulwark it must be, as strong and firm

and hard as the might of this German oak,

a castle royal it shall shine and gleam

o'er this land's gloomy forest night.

For I will rule here with force and firmness,

law and civilization

will be the people's lot,

who now live like beasts in the jungle

and on the river's reedy strand. (154)

I have shown how the text works with the opposition between ruler and people. The curious flavour of this antagonism becomes apparent here: the woman/people in the jungle of the humid fluvial plain is contrasted with the man/ruler, his eagle banner held aloft, who seeks to erect a castle on the hill. All elements of the account of this 'city founding' are indicated in a strikingly clear, contrast-rich fashion: using associative connections, they are assigned either to the male or the female sex and thus possess a gender identity. The 'young woman' on the banks of the 'raging torrent' represents the people who live here 'like beasts in the jungle'. This people is still without 'civilization', still totally at the mercy of its animal nature, as Klopstock asserted of the people 'floating in the stream of each passion, without hope of rescue' ${ }^{46}$

46 Grimms Wörterbuch, Vol. 10, Section 4, 1942, p. 30. 
On the other hand the armoured Romans, who plant their banners and then erect their castle-'strong and firm and hard'-suggest from the beginning the connection man-ruler-foreigner. The encounter between the woman at the river and the hard Roman men stands at the beginning of the history of Basel-but this origin is clearly not an historic act, but rather a procreative act: it unites the fecund and expectant fluvial plain with the Romans' hard, upright 'banner/sword/castle'. When the original population is overwhelmed and subjugated by the Romans it is a sexual act, in which the man/ruler bends the woman/people to his will. ${ }^{47}$ The men of the populace, in contrast, were incapable of 'conceiving' a city with their women: only the ruler's phallus rendered the people/woman fertile. The product of this procreative act was 'Basilea', the daughter of the foreign ruler and the local populace.

In this metaphor the pageant develops two discourses, the core of which becomes recognizable here: first the relationship between ruler and people, and second the relationship between man and woman. The first scene's metaphors unite these two levels-relations of authority and relations of gender-but still ambivalently. While the site of ruler and people is in each case unambiguous ('above' and 'below'), gender relations remain indeterminate: men belong both to the people and to the group of the rulers. Only women have their place down at the river.

\section{The Conquered Enemy and the Good Ruler}

The first scene's metaphors correspond completely to the images of genitals and coitus Freud analyses in his Interpretation of Dreams, which only serves to strengthen our suspicion that the founding of the city was imagined as a procreative act. ${ }^{48}$ This unambiguous imagery undergoes a fundamental transformation in the subsequent scenes, however. The bridge-building scene portrays a 'youth' being swept away to his death by the storm-lashed Rhine: the drastic portrayal of the river's dangers follows scenes of tranquil life upon its banks and of the sexual act between people and ruler. The Rhine no longer flows between the young woman on the bank and her lover. Instead it lurks, dark and dangerous, beyond the society of the town's hardworking populace. As early as the end of the first scene an as yet unknown 'enemy' unexpectedly

${ }^{47}$ Cf. Foucault's analysis of the corresponding dream metaphors in Artemidorus' Interpretation of Dreams. Michel Foucault, The Care of the Self. The History of Sexuality, Vol. 3 (London, 1988), pp. 30ff.

${ }^{48}$ It is important to note, however, that Freud only (and cautiously) used 'deciphering keys' to dreams if the corresponding images were comprehensible as symbols with a relatively stable meaning in (everyday) language, which was thus conceived of as an 'archive' (Foucault) of dream language. Cf. Freud, Interpretation of Dreams, p. 229, 462-470. On dream metaphors with a sexual content see pp. 232-235, 470. 
appears, who remains 'outside': Valentinian has just offered the people armed protection in exchange for their submission. Populace and warriors now join in singing

Long live the emperor, long may he live, the glorious founder of cities!

Loudly we praise, we praise in song, him who conquered our enemies! (156)

Shortly before the Romans had been the 'enemies' and the people on the river those being conquered. But now this same people rejoiced in the victory of 'him who conquered our enemies'. Who or what were these enemies, from whom the emperor apparently also liberated the people themselves? Let us take another look at the symbolism of the stream (Strom). This often has a metaphorical meaning of its own, without a woman on the banks: we find it, for example, in Gieseke's verses as a stream of longing:

from it and to it flowed, ever same, unchangeable

a stream of holy desire, not to be increased

or in Lenau:

plunged deep into the stream of longing

which has drunk up all my senses

or in Schiller:

and my swelling sensations may

overflow in voluptuous streams. ${ }^{49}$

Let us formulate a hypothesis here based upon these verses: in the pageant text the Rhine itself is to be interpreted metaphorically as passion, as a stream of desire, a torrent of sexual longings-at once enticing and threatening. Scenes 1 and 2 each formulate one side of the river metaphor: in Scene 2 the Rhine is no longer 'raging' as in the first scene, but rather a 'dark torrent' which draws the men who venture out upon it to their deaths. This altered imagery also determines the character of the entire second scene: the men of the populace, who have long since been taught 'civilization', work and cross the dangerous stream because 'high rewards were promised them'. The people no longer live along the river in a state of nature, but they are still subject to the nearby tides and the perilous stream of desire... Women and weak men incapable of defending themselves against such danger (that is, the people) thus turn to the bishop, the ruler of the town appointed by the foreign power of the Roman Curia. The scene is repeated: the foreign ruler, who founded/

49 All examples in Grimms Wörterbuch (Vol. 10, Section 4, 1942), p. 31. 
fathered the town, now donates the bridge and holds back the dark torrent, as the entire chorus sings:

Basel, thou sovereign,...

thou forcest waves and billows

under a harsh yoke, and yet

thou remainest free! (162)

It was the objective of the town's founder, Valentinian, to confront the river dwellers' nature-bound yearning for love with the ruler's principle of production. The 'Rhine Pass was closed' and the stream of desire channelled. The bishop as ruler of the town now seeks to create secure and sturdy channels for the other currents of transport and circulation of goods: 'processions of goods and currents of people', as the bishop says.

If we follow the hypothesis that stream $=$ desire, ${ }^{50}$ the pageant's first two scenes show how the stream of the people's desire, which produced nothing, is 'drained'. What dominates now is the principle of production, the principle of the ruler, the begetter of cities, the bridge-donor. And one sees here how the textual levels of 'ruler-people' and 'man-woman', which were still ambivalently linked in the first scene, begin to move apart. The men turn away from the river and towards work, while the women remain closer to the stream of desire by continuing to direct their yearnings towards their men and not, as the men do, towards objects of production. To be sure, under the ruler's régime, the women of the people have turned away from the original torrent of desire but they nonetheless continue to 'tremble' for their 'beloveds' and to be grateful to their 'fatherly' ruler.

The third scene shifts the emphasis once again. The river disappears almost entirely - and the ruler appears as a liberator. When King Rudolf of Habsburg rides into Klein-Basel he encounters a populace that finds its pleasure in labour, in the struggle against the 'enemy', and in wine. The men of the people love their work and are so far removed from the river that it only appears in a small detail-as the fishermen's workplace and source of wealth. This stream is neither ominous nor enticing, and logically enough the ruler also loses his immediate function as a result. He must not subjugate the people in order to lead them away from the river, and he does not need to build any bridges. He only comes to Klein-Basel to 'liberate' the hardworking people. The intervention of the foreign ruler decreases with the people's growing distance from the river. This means that as soon as the ruler's principle of production has been adopted so completely by the people that work itself

so On this see Klaus Theweleit, Männerphantasien, Vol. I (Frankfurt am Main, 1979), pp. 314 326. English: Male Fantasies, Vol. 1, Women, Floods, Bodies, History (trans. Stephan Conway et al.) (Cambridge, 1987). 
becomes a pleasure, the lord can return to his nominal protective function as king.

One thing, however, remains strangely unchanged. The 'maiden' who, together with the 'youth', sings a love song for the king, still follows her lover with 'trembling'; her sole 'delight' is to 'rest upon his breast'. Quite incidentally, but with growing explicitness, Wackernagel assigns to woman the role of continuing to represent this original desire and remaining tied to her 'beloved'.

\section{From 'Sempach' to Helvetia}

The liberation of the populace from its wildly acclaimed ruler forms the point of contact between the fictional stories and the more or less real history of the battle of Sempach. At Sempach the lord of Klein-Basel is actually killed. As was already shown above, Duke Leopold III of Austria rode off to battle against the Swiss confederates accompanied by the urban nobility and the curses of the citizenry. The battle itself, in which the peasants (the people) slay their lord somewhere in the far-off Swiss countryside, is not portrayed. Only 'behind the scenes', with the stage completely empty, does the citizens' choir sound:

Time conceals

in its womb

something unnameable

terrifyingly large.

Stifling and dark

falls the night

no more will the world

awake to light. (172)

The transition from the good to the evil ruler to which I referred above is also evident in the metaphors of these lines: something 'unnameable, terrifyingly large, in its womb' terribly frightens the citizens, the populace. Let us venture an interpretation: is it not possible that the 'unnameable', which resists more precise definition, is the formerly so revered phallus of the ruler from the first scene which, imbedded in the womb of time, has been the procreative principle moving history along during the millenium between the city's founding and Sempach? This reading seems to me at least plausible, even if the linguistic proximity of 'to see the light of day' (for 'to be born') is compared to the following phrase, which means the same in negative reversal: 
'no more will the world awake to light'. In other words, now the ruler's phallus has nothing more to beget/give. ${ }^{51}$

The text undertakes its final shift with the appearance of the three allegorical figures of Helvetia, Basilea, and Clio. Basilea, at once the 'daughter' and metonymy of the people who originally lived along the river, admits in retrospect, at the end of the story, that she never truly 'desired' all those foreign men, but rather that her 'ardent longing' had, essentially, always been for Mother Helvetia:

Behold, Helvetia, that was my childhood,

those the days of my unconscious youth [!],

when I was not yet thine, when a foreigner led me tightly bound

when liberty was but a distant sound

of splendour heretofore unknown

And 'twas thy liberty; 'twas from thee

that the tone first rang out, that my heart cried

joyfully for thee, desiring thine.

But oh, how long my time of trial until,

this ardent longing was fulfilled. (175)

Why does the text once again make Basilea utter the obvious hypocrisy that a foreigner led her 'tightly bound' 'when I was not yet thine'? Why can she not maintain her original desire, why does she deny the foreign man with the statement that she only ever desired the 'Mother'? The good Helvetia does not know either, she simply makes the point 'thou camest not' 'until my heroic sons forged with their swords a path from me to thee', etc.: in other words, until 'Sempach'. Historically, the battle of 1386 by no means brought Basel into the Swiss confederation, but here, too, the pageant's national mythology fixes 'Sempach' as the turning point. At the end of the play, therefore, the two women stand alone on the stage, united by a deep love for one another. The stream flows one last time:

[Helvetia:]

So long as the green billows

of the Rhine, son of the Alps,

roll past thy foot, our union shall

endure, shielded by the Most High! (178)

Banished forever is the peril of the dark torrent: it has been miraculously transformed into a friendly 'son of the Alps', a messenger sent down by

s1 Perhaps I should point out here that I use the term phallus in the conventional sense as a 'symbol' of male potency and procreative power, and not in the Lacanian sense, where the phallus is a signifier that produces meaning. 
Mother Helvetia from her cold snow-mountains, whose billows are neither wild nor foaming, neither dark nor engulfing, but rather green, cool, and rolling. This final image, with its strange metaphor of a deep mother-daughter relationship, still harbours something significant, however: Where are the men? Who rules now?

\section{The Bourgeoisie as a Knightly Army}

The official account of the festival, like the festival programme that preceded it, lists the names of the pageant actors next to their roles. ${ }^{52}$ These names can be combined with information on income and occupation ${ }^{53}$ and as names they point to the family's position on the urban scale of gentle birth and prestige. This combination of social factors determined who was cast in which role. As in the processions in historical costume that remained common throughout the nineteenth century, in the pageant too 'the theatrical processional hierarchy corresponded completely to the bourgeois hierarchy of influence'. ${ }^{54}$ If one conceives of 'bourgeois influence' as a combination of income, occupation, and family name, then this hierarchy of influence or social status pyramid also stamped its own social logic on the distribution of roles in the Basel pageant. The 'lords' of former times were played by members of the present-day upper middle classes, and the 'citizenry' or 'populace' of the medieval city were played at appropriate social intervals by artisans, shopkeepers, and salaried employees. ${ }^{55}$

This socio-historical viewpoint, which attributes discursive phenomena to social conditions in the sense of a functionalist sociology, would have found almost perfect confirmation in the Basel pageant. It is doubtless not insignificant for the production of meaning in this dramatization that everybody knew who was playing each role. ${ }^{56}$ As a discursive event, however, the pageant cannot be reduced to such considerations. Even had the text been performed by professional actors, the question would still arise as to why thousands of spectators were so enthusiastic about this touchingly earnest topical verse.

${ }^{52}$ Basler Vereinigungsfeier. Officieller Festbericht, Appendix 4 'Das Festspiel' (cast list), pp. 122-127.

${ }_{53}$ Basler Steuerbücher (Staatsarchiv Basel, Steuern N 4); for a detailed account see also Sarasin, Stadt der Bürger, Chapter 8, pp. 339-348.

${ }_{44}$ Theo Gantner, Der Festumzug. Ein volkskundlicher Beitrag zum Festwesen des 19. Jahrhunderts in der Schweiz (exhibition catalogue, Museum für Volkskunde Basel) (Basel, 1970), p. 30. This finding is generic; cf. for example Maurer, 'Feste und Feiern', p. 116.

${ }^{55}$ See the table in Sarasin, Stadt der Bürger, Anhang B, pp. 448-451.

${ }_{56}$ In the copy of the festival account I bought from an antiquarian bookseller someone had written in under the photographs of the various scenes the names of extras mentioned nowhere in the official cast lists. The names of the principal actors and actresses were naturally listed in the programme. Most of them were well-known people, and some were even celebrities in the public life of the town. 
One may discuss the issue in two steps. First, one could show (which I however do not wish to do here) that 'good' rulers always also announce their political programme. It is surely not surprising that the pageant's explicitly political discourse is identical to the political notions of the civic élites, the social policy credo of the ruling classes in Basel at the end of the nineteenth century. ${ }^{57}$ In their eyes, it was indeed they themselves who channeled the pauperized masses' streams of desires, bringing them under the yoke of the eleven-hour day and the rhythm of machines. It was with their capital, in their factories, that the dull 'beast-like' labour power of the people was rendered fruitful and productive, as one might put it paraphrasing the words of the Emperor Valentinian. They 'civilized' the rural proletarianized masses by integrating them into urban industrial culture. ${ }^{58}$ Beneath the veil of historical images the pageant conveyed the message that the people needs a ruler. Without the rule of the bourgeoisie this 'civilizing process' would never succeed.

This, then, is a first approach to an explanation: here we see the first shimmer of the desire that provided the impetus for the entire production, the desire not only of the playacting bourgeois ladies and gentlemen, but also of their enthusiastic audience to rule as the emperor, the bishop, or the king does. This wording is itself metaphorical. One might, with all due caution, phrase it as the desire to organize power like an emperor or a king even outside the factory, and to win the people's absolute respect for their authority just as they erroneously imagined that the rulers portrayed in the pageant had done. In its first scenes the pageant dreamed of transferring the patriarchal model of authority (which still existed in the silk industry with its traditional capital structure $)^{59}$ to the political arena where, over the course of the nineteenth century, a rationalization of authority had occurred in which the old urban élites steadily lost influence. ${ }^{60}$

Michel de Certeau has located the 'centre de la découverte freudienne' in that very process of which we are speaking here: 'Le retour du refoulé', ${ }^{61}$ the return of the repressed. The playacting gentlemen of 1892 allowed themselves the pleasure of conjuring up a 'history' on the stage that corresponded to the spirit of the times. They would have denied vehemently any suggestion that, in portraying historical rulers, they were really saying something about

57 Cf. Carl Sarasin, Die Stellung der grossen Gewerbe zu den darin beschäftigten Arbeitern (Basel, 1868); Alphons Koechlin-Geigy, Ueber Streiks und die Arbeiterfrage (Basel, 1889) and Das Recht auf Arbeit (Basel, 1892); Johann R. Geigy-Merian, Zur Arbeiterfrage (Basel, 1891). See also Georg Adler, Basels Sozialpolitik in neuester Zeit (Tübingen, 1896).

${ }^{58}$ Cf. Emil Dürr, 'Urbanität und Bauerntum in der Schweiz', in Die Schweiz. Ein nationales Jahrbuch-1934 (ed. Neue Helvetische Gesellschaft, Vol. 5.) (Erlenbach-Zurich, 1934).

${ }^{59}$ On the capital structure of the Basel silk ribbon industry see Sarasin, Stadt der Bürger, pp. $109-111$.

${ }^{60}$ Martin Schaffner, 'Geschichte des politischen Systems von 1833-1905', in Burckhardt $e t$ al. (eds), Das politische System Basel-Stadt, pp. 37-54.

${ }_{61}$ Michel de Certeau, Histoire et psychanalyse entre science et fiction (Paris, 1987), p. 97. 
themselves: the stage was a place of pure patriotic sentiment, cleansed for the holiday of all social conflict. And yet that was precisely what they were doing: 'l'exclu s'insinue de nouveau dans cette place 'propre', il y remonte, il l'inquiète'. ${ }^{62}$ The past and the repressed persist, as Marx had already recognized, into the present, as the pageant, which is so much like a dream, demonstrates: 'Il y a partout des jeux de masques, de retournement et d'ambiguité. ${ }^{63}$

One may still wonder, however, why an upper class rendered highly cohesive by the practices of social endogamy, ${ }^{64}$ with ample opportunities to represent its hegemonic social position and turn it to its own advantage, would go to all this trouble? Why the repression, which turned a patriotically intended pageant into a jeu de masques of bourgeois phantasms? Finally, why was it necessary for the good ruler to mutate into an evil one? In a second explanatory step I should like to show that the pageant as 'dream' represents the attempt to resolve the 'dreamer's' inner conflict, in which his above-mentioned desire has involved him. This is precisely the true task of myth according to Claude Lévi-Strauss: 'l'objet du mythe est de fournir un modele logique pour résoudre une contradiction (tâche irréalisable, quand la contradiction est réelle)' ${ }^{65}$

By the republican standards of political discourse in nineteenth-century Basel (and Switzerland), the desire to wield authority not merely as a patriarchal employer in the factory, but also to 'rule' in the political sense was (analogous to Freud's definition of repressed desire) illegitimate, even obscene. After all, the political consensus underlying the establishment of the federal state in 1848 rested on the assumption of an equality of citizens in the republic, on the democratic legitimation of political power and the rejection of a ruler or a ruling class as it had existed under the old régime. ${ }^{66}$ In the final quarter of the century the leading bourgeois élites saw themselves criticized at precisely this point by the social democrats who, despite their moderation and ambivalences contested the unquestioned hegemony of the old and new bourgeois élites and their liberal capitalist model of society. The social democrats were, to be sure, grateful for the struggle for political freedom that had been waged by the liberals, and they shared the bourgeoisie's patriotic

${ }^{62}$ Certeau, Histoire, p. 98.

${ }^{63}$ Certeau, Histoire, p. 99. Cf. Karl Marx, 'The Eighteenth Brumaire of Louis Bonaparte', in Marx, Political Writings, Vol. 2, Surveys from Exile (ed. David Fernbach) (London 1973), pp. 143-249, p. 148.

${ }_{64}$ On the symbolic practices for cementing the social cohesion of a ruling group see Philipp Sarasin, 'Une coutume barbare. Les fonctions signifiantes de l'argent dans une société bourgeoise vers 1900', Geneses. Science sociale et histoire 15 (March 1994), 84-102; see also further information on local history in Sarasin, Stadt der Bürger, Part II. The classic study is Norbert Elias, The Court Society (trans. Edmund Jephcott) (Oxford, 1983), for example pp. 117-145.

${ }_{65}$ Claude Lévi-Strauss, Anthropologie structurale (Paris, 1958), p. 254.

${ }^{66}$ See Albert Tanner, 'Bürgertum und Bürgerlichkeit in der Schweiz. Die "Mittelklassen" an der Macht', in Jürgen Kocka and Ute Frevert (eds.), Bürgertum im 19. Jahrhundert. Deutschland im europäischen Vergleich (Vol. 1) (Munich, 1988), pp. 193-223. 
belief in the political systems of 1848 and $1874,{ }^{67}$ respectively, but they also denounced ever more vociferously the liberal promise of equality upon which the federal state of 1848 had been founded, pointing to the detestable reality of class differences and class rule. ${ }^{68}$ This social democratic opposition to the fundamental bourgeois consensus and to the bourgeois desire, expressed in the pageant, to live out the status of ruler without constraint, created the contradiction that required mythological resolution and 'reconciliation'. In its final two scenes, the pageant had to present a model for this, a model for the creation of creating bourgeois meaning and consensus.

\section{The Death of the Ruler}

This model is based upon the necessity of the ruler's death. It thus follows the Hegelian dialectic of master and servant exactly: as is well known, Hegel perceived the master's nature in the fact that the servant trembled before him and recognized him as master ${ }^{69}$ And the servant works for the master, who has access to the thing only via the other's labour-all that remains for the master is the enjoyment of the thing, satisfaction, pleasure. For Hegel, the truth is that 'this satisfaction is itself only a fleeting one, for it lacks the side of objectivity and permanence. Work, on the other hand, is desire held in check, fleetingness staved off; in other words, work forms and shapes the thing'. ${ }^{70}$ We have seen how the ruler demanded sublimation of his people, i.e., a turning away from the stream of desire and towards work. In that part of Scene 4 in which a citizen recalls the so-called 'evil carnival' of 1376 (a revolt against the duke and the local nobility), the now hardworking people suddenly discover that the ruler, as a non-working knight, is himself just as 'deceitful' (as the bishop called the waters of the Rhine in Scene 2) and as pleasurably excited as the now tamed river once was. Ever since the act of procreation that led to the creation of the city all that remained to the ruler was pleasure, which the pageant presents as sexual pleasure, something that the populace has rejected in favour of 'education' through work. The populace's pleasure, as 'repressed desire', is tied to work, as the third scene shows, and their self-confidence grows, in the pageant as in Hegel, as a product of this process of education through labour. Meanwhile, the ruler increasingly loses his function. In this dialectical movement the servant loses his fear of the master-and kills him. ${ }^{71}$

${ }^{67}$ At that time not only was the all but unlimited protection of property anchored in the constitution, but the 'Volksrechte' were also extended to include the legislative referendum as a means of direct democracy. See Eduard His, Geschichte des neueren Schweizerischen Staatsrechts, Vol. 3, Der Bundesstaat von 1848 bis 1914 (Basel, 1938), pp. 346f.

${ }^{68}$ See Erich Gruner, Die Parreien in der Schweiz (Berne, 1977) (1969), pp. 127-130; and Winfried Haeberli, Die Geschichte der Basler Arbeiterbewegung von den Anfängen bis 1914. Vol. 1 (Basel, 1986), pp. 96f.

${ }_{69}$ Georg Wilhelm Friedrich Hegel, Phenomenology of Spirit (trans. A. V. Miller, ed. J. N. Findlay) (Oxford and New York, 1977), pp. 115-118.

${ }^{70}$ Hegel, Phenomenology of Spirit, p. 118.

${ }^{7}$ Hegel, Phenomenology of Spirit, p. 119. 
The fourth scene and epilogue complete a double movement. The ruler disappears, and in his place appear, first offstage in the account of the messenger from Sempach, the hero Winkelried, and then on the empty stage, the Muse Clio, the national allegory Helvetia, and Basilea, who has given up her original relationship with the foreign man: Winkelried has slain him. Swiss historiography of the late Middle Ages created the image of the hero Winkelried ${ }^{72}$ who in 1386 caught as many enemy spears as he could hold in his arms and pressed them into his breast, thus opening a gap in the forest of enemy spears for the confederate Swiss peasant troops, who had been unsuccessfully storming the phalanx of knights. The significance of this myth does not lie in the (incidentally incorrect ${ }^{73}$ ) details of military technique. Instead, following the usual topoi (i.e. the myth of Christ ${ }^{74}$ ) the message is that one man sacrificed himself for all, but with the specific twist that one man took upon himself the guilt for killing the ruler.

The ideology of a free Switzerland, subject to no overlord, and of the free Swiss was able to develop thanks, among other things, to the construction by sixteenth-century élites of the hero Winkelried. At least the visible lord, i.e., the foreign ruler, was now dead. ${ }^{75}$ Here is the successful attempt to halt, in mythical discourse, the Hegelian dialectic of master and servant. And it is precisely this aspect of the Winkelried myth-that the hero killed the foreign ruler (and not his own master)-that also functions in the pageant as the cunning solution of Basel's 'patrician' lords who are compelled to show how they escape the ominous dialectic of master and servant: their authority evades this dialectic by allowing the visible ruler, mounted in his knight's armour, to be slain 'offstage' by the 'confederate Swiss brethren'. They succeed in this because in the pageant they are playing two cards simultaneously: they appear as citizens naturally represented by the populace that frees itself from feudal servitude in the fourth scene-and, at the same time, as the economic and political leaders of the present, they are also those rulers in shining armour whom the populace cheers. Playing the rulers themselves was, perhaps, not quite necessary.

The pageant does not show how domination could be overcome: it could have followed the real, known history of the city in Scenes 1-3 and dramatized credibly the populace's emancipation through work from the town's ruler.

72 Guy P. Marchal, 'Leopold und Winkelried-Die Helden von Sempach, oder: Wie ein Geschichtsbild entstand', in Arnold von Winkelried, Mythos und Wirklichkeit (Stans, 1986) (Nidwalder Beiträge zum Winkelried-Jahr 1986).

${ }_{73}$ Marschal, 'Leopold', p. 90.

$74 \mathrm{On}$ the discursive usability of the myth of Christ in nineteenth-century Swiss heroic mythology, see my essay "'Ihr Tod war unser Leben". Die St. Jakobsfeiern im 19. und frühen 20. Jahrhundert', in Werner Geiser (ed.), Ereignis-Mythos-Deutung. 1444-1994 St. Jakob an der Birs (Basel, 1994), pp. 83-125, esp. pp. 100-117.

${ }^{75}$ Suter, Winkelried, pp. 55-76. 
Had this ruler disappeared at the end, the void he left could have been convincingly redefined by the abstract principle of popular sovereignty. ${ }^{76}$ In fact, however, by means of a simple conjuring trick, a trick hinted at only in the text's contradictions, the pageant makes domination disappear behind the façade of an allegorical mother-daughter relationship. Why did the trick work? Why were such historical mythologies, which placed a Mother Helvetia in the empty space left by the dead ruler, believable? ${ }^{77}$

\section{A Family History?}

The pageant contains a few elements that might prompt us to return to Freud. We recall that the daughter Basilea was a product of the original sexual relationship between the foreign ruler and the people, who, as we know, were identified not only in the pageant with a woman. ${ }^{78}$ If we follow Freud's advice to 'have faith in the believers who call God their father ${ }^{79}$ and take this role division seriously, the text remains ambiguous from this point forward: as the play goes on it is at times the people, i.e. Basilea's mother, and at times Basilea, the daughter, who has a relationship with the ruler, who is now increasingly addressed as father. This relationship is no longer openly sexual, but determined more by the ruler's paternal character. These were the 'days of my unconscious youth', as Basilea apologetically explains in retrospect, the time of her connection to a man who could have been her father, or to her father, who she desired as a man. It is surely no coincidence that the imagination of the pageant's author and of the upper middle class organizers, actors and spectators who supported and encouraged him did not simply place an erotic connotation on the story of a politically illegitimate power relationship but also, as we must state more precisely here, clothed it in the guise of Oedipal desire: I have already noted that the micro-power in the silk industry's factories was understood and organized patriarchally. ${ }^{80}$

${ }^{76} \mathrm{Cf}$. Dian Schefold, Volkssouveränität und repräsentative Demokratie in der schweizerischen Regeneration, 1830-1848 (Basel, 1966).

"Georg Kreis' observation that the figure of Helvetia rarely appears in the imagery of the period before 1800 (i.e., the old regime), and only became a symbol of national unity and community in the course of the nineteenth century, is interesting in this context. Georg Kreis, Helvetia-im Wandel der Zeiten. Die Geschichte einer nationalen Repräsentationsfigur (Zurich, 1991), pp. 28, 32-40. The mythological transition from Winkelried to Helvetia was dramatized on a grand scale for the first time at the $\mathbf{1 8 8 6}$ celebrations of the battle of Sempach. See Widmer, Die Schweiz in der Wachstumskrise, p. 642.

${ }^{78} \mathrm{Cf}$. Susanna Barrows, Distorting Mirrors. Visions of the Crowd in Late Nineteenth-Century France (New Haven and London, 1981).

${ }^{79}$ Sigmund Freud, Totem and Taboo (Penguin Freud Library, Vol. 13) (London, 1990), pp. 43-224, p. 209.

${ }^{80}$ Eduard His still affords the best glimpse-if without much critical distance-of the 'mentality' of Basel entrepreneurs of this era in his Basler Handelsherren des 19. Jahrhunderts (Basel, 1929). See also his Basler Staatsmänner des 19. Jahrhunderts (Basel, 1930). 
We may thus assume that the model of a bourgeois creation of meaning described above, which sacrifices the visible ruler in favour of the invisible, also has a psychoanalytically describable background. Wackernagel was not simply a bad poet. At least he remained consistent and was obliged to find a way out for a desire which in his text served to make the original relationship of domination somewhat plausible. When, at the end, he recounts that Basilea joined forces with the Swiss confederates, he thus says:

Then Basel felt this ardent courtship's masterful form and surrendered. (177)

A sexual act. Now, however, it was no longer a 'ruler', but rather the 'sons' of Mother Helvetia who, for a brief moment (two lines) take Basilea as a wife. At Sempach these 'heroic sons', like a 'horde of brothers', killed the old father/ruler ${ }^{81}$ If the 'brothers' league', the 'league of confederates' is to continue to exist, then none of these sons may claim Basilea for his own, as we may assume along with Freud.

And in fact, Basilea's 'surrender' does not lead to a relationship with one of the 'heroic sons', but rather straight to the bosom of Helvetia, whom she now calls 'Mother'. Why is this plausible? Did the enthusiastic spectators follow the imaginings of the pageant's author precisely because he made Basilea renounce all erotic and Oedipal desires and sent her back to her mother - in a position of hysterical desire? ${ }^{82}$ This was doubtless not a particularly happy solution for the women. ${ }^{83}$ For the men, in contrast, the motherdaughter masquerade at any rate obscured the fact that bourgeois men who exerted power over their subordinates 'like fathers' associated this power with sexual desire. ${ }^{84}$

The analysis of the play has at any rate shown us how the ruler disappears along with the river's domestication in favour of bourgeois work: in other words, how domination is forced out of the symbolic order, eliminated from discourse. Now it becomes clear that, in the perspective of this text, it is women who pay the price. At the end of the pageant play Basilea must renounce her by no means unhappy relationships because the men who wield power must disappear. While the men in the pageant became 'brothers without a ruler', men whose political, economic and sexual power no longer has a

${ }^{81}$ Cf. Freud, Totem and Taboo, pp. 196-207.

${ }^{82}$ On the concept of hysteria see Lucien Israël, L'hystérique, le sexe et le médecin (Paris, 1976).

${ }^{83}$ On the close connection between hysteria and the female gender role in the nineteenth century see Carroll Smith-Rosenberg. 'The Hysterical Women: Sex Roles and Role Conflict in 19th-Century America', Social Research 39 (1972), 652-678.

${ }_{84}$ This is an extensive topic; see, for example, Regina Schulte, Sperrbezirke. Tugendhaftigkeit und Prostitution in der bürgerlichen Welt (Frankfurt am Main, 1979). 
name, the women, idealized as loving mothers and happy daughters, are left behind with their desires at the river, like 'children of nature' ${ }^{85}$

One might, perhaps, decode the rebus of this bourgeois pageant thus: while men have power, women are allowed to represent it-for instance as national allegories, of which Jacob Burckhardt remarked that they were generally pictured as 'great streams'. ${ }^{86}$

(Translated by Pamela Selwyn)

${ }^{85}$ The pageant did not, of course, reinvent its 'truths'. On the equation 'woman = nature' see, for example, Karin Hausen, 'Die Polarisierung der "Geschlechtscharaktere". Eine Spiegelung der Dissoziation von Erwerbs- und Familenleben', in Werner Conze (ed.), Sozialgeschichte der Familie in der Neuzeit Europas (Stuttgart, 1976), pp. 363-393. English: 'Family and Role-division: The Polarisation of Sexual Stereotypes in the Nineteenth Century-An Aspect of the Dissociation of Work and Family Life' (trans. Cathleen Catt), in Richard J. Evans and W. R. Lee (eds), The German Family: Essays on the Social History of the Family in 19th-and 20th-century Germany (London, 1981), pp. 51-83; or Carol P. MacCormack, 'Nature, Culture and Gender: A Critique', in Carol MacCormack and Marilyn Strathern (eds), Nature, Culture and Gender (Cambridge. 1992) (1980), pp. 1-24, esp. pp. $17 \mathrm{ff}$.

86 Jacob Burckhardt, 'Die Allegorie in den Künsten', in Vorträge (ed. Emil Dürr) (Basel, 1919), p. 301. 